\author{
P.P. Gorbyk ${ }^{1}$, A.L. Petranovska ${ }^{1}$, N.V. Kusyak ${ }^{2}$, N.M. Korniichuk ${ }^{1}$, A.P. Kusyak ${ }^{1}$, \\ O.I. Oranska ${ }^{1}$, T.V. Kulyk ${ }^{1}$, B.B. Palianytsia ${ }^{1}$, O.A. Dudarko ${ }^{1}$
}

\title{
ADSORPTION OF CISPLATIN BY THE SURFACE OF THE MAGNETIC SENSITIVE NANOCOMPOSITE $\mathrm{Fe}_{3} \mathrm{O}_{4} / \mathrm{Al}_{2} \mathrm{O}_{3} / \mathrm{C}$
}

\author{
${ }^{1}$ Chuiko Institute of Surface Chemistry of National Academy of Sciences of Ukraine \\ 17 General Naumov Str., Kyiv, 03164, Ukraine, E-mail: petranovska@ukr.net \\ ${ }^{2}$ Ivan Franko Zhytomyr State University \\ 40 Velyka Berdychivska Str., Zhytomyr, 10008, Ukraine
}

\begin{abstract}
One of the most widely used antitumor chemotherapeutic drugs is "Cisplatin" (active substance - cisdiaminodichloroplatinum), the side effects of which are the cumulative ototoxic, nephrotoxic and neurotoxic effects. The use of drug carrier systems for targeted delivery and adsorbents for extraction, in particular magnetite-carbon nanocomposites, will minimize unwanted toxic effects without reducing the therapeutic effect of cisplatin.

For this purpose, a nanocomposite (NCS) of $\mathrm{Fe}_{3} \mathrm{O}_{4} / \mathrm{Al}_{2} \mathrm{O}_{3} / \mathrm{C}$ with a carbon surface was synthesized, where a layer of alumina protects magnetite during the pyrolysis of carbohydrates. The synthesized samples were characterized by TEM, $X R D$, mass spectrometry methods, magnetic properties and specific surface area were studied. It has been found that the used heat treatment mode $\left(T=500^{\circ} \mathrm{C}\right.$, argon medium) is sufficient for complete carbonization of sucrose and preserves the phase of magnetite which does not lead to deterioration of magnetic characteristics. The results of TEM studies and magnetic measurements indicate the formation of the $\mathrm{Fe}_{3} \mathrm{O}_{4} / \mathrm{Al}_{2} \mathrm{O}_{3} / \mathrm{C}$ nanocomposite of the core-shell type.

The adsorption of Cisplatin on the surface of $\mathrm{NCs} \mathrm{Fe}_{3} \mathrm{O}_{4} / \mathrm{Al}_{2} \mathrm{O}_{3} / \mathrm{C}$ was performed and the adsorption process dependent on the contact time, $\mathrm{pH}$ of the solution and cisplatin concentration was studied. The experimental results of kinetic studies were analyzed for compliance with the theoretical models of Boyd and Morris-Weber, models of pseudofirst and pseudo-second orders. Langmuir and Freundlich isotherm models were used to model adsorption processes. The limiting factor of adsorption is the external diffusion mass transfer processes, which correlates with the calculated parameters of the pseudo-first-order model $\left(r^{2}=0.985\right)$. The correlation of theoretical and practically obtained values of adsorption capacity indicates the possibility of using the Freundlich model to describe the adsorption of Cisplatin on the surface of $\mathrm{Fe}_{3} \mathrm{O}_{4} / \mathrm{Al}_{2} \mathrm{O}_{3} / \mathrm{C}$.
\end{abstract}

Keywords: magnetosensitive nanocomposites, carbon surface, carbonization, Cisplatin, adsorption

\section{INTRODUCTION}

Among the nanodisperse magnetically sensitive materials used to create multifunctional nanocomposites (NCs), magnetite $\left(\mathrm{Fe}_{3} \mathrm{O}_{4}\right)$ and its modified forms occupy an important place due to their unique physicochemical and biological properties [1-6]. In particular, NCs based on single-domain $\mathrm{Fe}_{3} \mathrm{O}_{4}$ with a core-shell structure and hierarchical multilevel nanoarchitecture, capable of performing the functions of medical-biological nanorobots [7-15]: recognition of specific cells, viruses and biomacromolecules in biological media; targeted delivery and deposit of drugs in cells and target organs; complex local chemo-, immuno-, neutron-capture-, hyperthermic-, photodynamic therapy and magnetic resonance imaging diagnostics in real time; detoxification of the body by adsorption of degradation residues of cells, viral particles, heavy metal ions, etc. and their removal by magnetic field is a priority.

(C) P.P. Gorbyk, A.L. Petranovska, N.V. Kusyak, N.M. Korniichuk, A.P. Kusyak, O.I. Oranska, T.V. Kulyk, B.B. Palianytsia, O.A. Dudarko, 2021
Reducing aggregation and increasing the size of the specific surface area of nanoparticles (NPs), the possibility of optimizing the magnetic and adsorption properties is achieved by modifying the surface with carbon [16]. Such nanocomposites with high adsorption capacity are controlled by a magnetic field, so the stage of extraction of spent adsorbent can be carried out by magnetic separation.

The aim of this work is to determine the adsorption properties of the surface of carboncontaining nanocomposite $\mathrm{Fe}_{3} \mathrm{O}_{4} / \mathrm{Al}_{2} \mathrm{O}_{3} / \mathrm{C}$ relative to the Cisplatin which is the most widely used antitumor chemotherapeutic drug.

\section{MATERIALS AND METHODS OF RESEARCH}

Magnetite when heated in an oxygen-free environment retains its magnetic properties to the Curie point $\left(585{ }^{\circ} \mathrm{C}\right)$ and can be heated to $800^{\circ} \mathrm{C}$ without changing its magnetothermal characteristics. In air due to the oxidation of magnetite at a temperature of $250-300{ }^{\circ} \mathrm{C}$, 
maghemite $\left(\gamma-\mathrm{Fe}_{2} \mathrm{O}_{3}\right)$ is formed, and when the latter is heated in air to temperatures exceeding $350{ }^{\circ} \mathrm{C}$, hematite $\left(\alpha-\mathrm{Fe}_{2} \mathrm{O}_{3}\right)$ is formed [17]. This phase transition leads to a significant deterioration of the magnetic properties. It is also known that the shell of oxides around the $\mathrm{Fe}_{3} \mathrm{O}_{4}$ nucleus, such as $\mathrm{SiO}_{2}$, during heat treatment of samples [2] to some extent stabilizes its chemical composition and magnetic properties. Previous studies have shown that the best way to achieve this goal may be to use magnetite with a modified $\mathrm{Al}_{2} \mathrm{O}_{3}$ surface.

Thus, the thermal stability of NCs $\mathrm{Fe}_{3} \mathrm{O}_{4} / \mathrm{Al}_{2} \mathrm{O}_{3}$ was sufficient to maintain the magnetic properties of the NCs nucleus in the temperature range of sucrose pyrolysis. Therefore, low-temperature pyrolysis (up to $550{ }^{\circ} \mathrm{C}$ ) in an inert medium (Ar) was chosen to form carbon-containing coatings in the structure of $\mathrm{NCs} \mathrm{Fe}_{3} \mathrm{O}_{4} / \mathrm{Al}_{2} \mathrm{O}_{3} / \mathrm{C}$.

Synthesis of nanosized $\mathrm{Fe}_{3} \mathrm{O}_{4}$. Nanodisperse magnetite in the single-domain state was synthesized by the Elmore reaction [6]:

$$
\mathrm{Fe}^{+2}+2 \mathrm{Fe}^{+3}+8 \mathrm{NH}_{4} \mathrm{OH} \rightarrow \mathrm{Fe}_{3} \mathrm{O}_{4}+4 \mathrm{H}_{2} \mathrm{O}+8 \mathrm{NH}_{4}{ }^{+} .
$$

The synthesized $\mathrm{NPs} \mathrm{Fe}_{3} \mathrm{O}_{4}$ in the original ensemble were characterized by sizes $3-23 \mathrm{~nm}$ and a single-domain state. The average size ( $\left.D_{\mathrm{XRD}}\right)$, determined by Scherrer's formula, was $10.5 \mathrm{~nm}$. The specific surface area of the synthesized magnetite was $S_{s p}=105 \mathrm{~m}^{2} / \mathrm{g}$. Magnetite was characterized by a coercive force $H_{\mathrm{c}}=55.0 \mathrm{E}$, specific saturation magnetization $\sigma_{s}=56.2 \mathrm{Gs} \cdot \mathrm{cm}^{3} / \mathrm{g}$, relative residual magnetization $M_{r} / M_{s}=0.2[12,14]$.

Synthesis of NCs $\mathrm{Fe}_{3} \mathrm{O}_{4} / \mathrm{Al}_{2} \mathrm{O}_{3}$. The synthesis of aluminum-containing coating on the surface of $\mathrm{Fe}_{3} \mathrm{O}_{4}$ was carried out by double chemical modification with aluminum isopropylate [18] according to the scheme:

$$
\text { - }-\mathrm{OH}+\left(\mathrm{C}_{3} \mathrm{H}_{7} \mathrm{O}\right)_{3} \mathrm{Al} \rightarrow \text { l-O-AlO}(\mathrm{H})+3 \mathrm{C}_{3} \mathrm{H}_{7} \mathrm{OH} \text {, }
$$

with subsequent polycondensation of the products of hydrolysis of aluminum isopropylate on the surface of the carrier.

The weight of the modifier was calculated by the formula:

$m=n \cdot g A M$.

Note: $M-$ is the molecular weight of the modifier; $A$ - the number of hydroxyl groups on the surface of magnetite, mol; $n=3$ - excess modifier, $g$ - weight of the carrier (magnetite), g.
Synthesis of $\mathrm{NCs} \quad \mathrm{Fe}_{3} \mathrm{O}_{4} / \mathrm{Al}_{2} \mathrm{O}_{3} / \mathrm{C}$. The obtained $\mathrm{NCs} \quad \mathrm{Fe}_{3} \mathrm{O}_{4} / \mathrm{Al}_{2} \mathrm{O}_{3}$ was impregnated using a rotary evaporator with sucrose solutions at the rate of $0.45 \mathrm{~g}$ of carbohydrate per $1 \mathrm{~g} \mathrm{NCs}$. Carbonization of the carbohydrate shell of NCs was carried out in argon at $500{ }^{\circ} \mathrm{C}$ for 2 hours in a furnace with programmable heating (heating rate $10 \mathrm{deg} \mathrm{min}^{-1}$ ).

XRD analysis. The crystal structure of NPs was determinated by powder X-ray diffraction method (XRD). XRD measurements were perfomed using DRON-4-07 diffractometer with $\mathrm{Co} K_{\alpha}$ radiation and $\mathrm{Fe}$ filter, focusing on BraggBrentano.

Mass spectrometry analysis. The completeness of carbonization of the surface layer of the carbohydrate was evaluated by the method of TPD MS (MX-7304A (Sumy, Ukraine)) with electron impact ionization $[19,20]$.

Magnetic properties. The magnetization of the samples was measured using a vibrating magnetometer at the frequency of $228 \mathrm{~Hz}$ at room temperature [11].

TEM study. Investigation of morphology and size distribution of NPs were performed in aqueous solutions (Transmission Electron Microscope JEOL 1200 EX (Tokyo, Japan)).

The specific surface area. The specific surface area of the samples was determined by the method of adsorption-desorption of nitrogen (KELVIN 1042 Sorptometer "COSTECH Instruments").

Study of Cisplatin adsorption. Chemotherapeutic drug "Cisplatin-Teva", which was used in the work, manufactured by Pharmachemi BV, the Netherlands (series 14C04KA).

The adsorption study of the drug Cisplatin was performed in physiological saline $(0.9 \% \mathrm{NaCl}$ solution) in the range of concentrations $C_{0}=0.0211-0.118 \mathrm{mg} / \mathrm{ml}(\mathrm{g}=0.03 \mathrm{~g}, V=5 \mathrm{ml}$, $\mathrm{pH}=5-6, T=296 \mathrm{~K}, \tau=180 \mathrm{~min})$ in static mode. The concentration of platinum ions in the contact solutions before and after adsorption was determined by the AAS method (AAS (C-115 M) fuel oxide system: acetylene-air, $\lambda_{\mathrm{Pt}}=265.9 \mathrm{~nm}$; sensitivity $0.1 \mathrm{mg} / \mathrm{l})$. The required $\mathrm{pH}$ values were set by adding $0.1 \mathrm{M}$ solutions of $\mathrm{HCl}$ or $\mathrm{NaOH}$ (Titrisol, Merck).

The adsorption capacity $A(\mathrm{mg} / \mathrm{g})$ was calculated with equation (1):

$$
A=\left(C_{0}-C_{e q}\right) \cdot V / g(1) \text {. }
$$


The removal efficiency $(R)$ was obtained with equation (2):

$R=\left(\left(C_{0}-C_{e q}\right) / C_{0}\right) \cdot 100 \%$

where $C_{0}$ and $C_{e q}$ - concentration of initial solution and solution after adsorption $(\mathrm{mg} / \mathrm{ml})$, $V$ - volume of solution (ml), $g$ - mass of sorbent (g).

Spectrophotometric analysis. Determination of absorption spectra was performed by spectrophotometric analysis (Spectrometer Lambda 35 UV/Vis Perkin Elmer Instruments).

\section{RESULTS AND DISCUSSION}

Sinthesis and structure research of $\boldsymbol{F e}_{3} \mathrm{O}_{4} / \boldsymbol{A l}_{2} \mathrm{O}_{3} / \boldsymbol{C}$ nanocomposite. $\mathrm{Fe}_{3} \mathrm{O}_{4} / \mathrm{Al}_{2} \mathrm{O}_{3} / \mathrm{C}$ nanocomposite was synthesized. Methods of XRD analysis (Fig. 1), mass spectrometry (Fig. 2) and study of magnetic properties (Fig. 3) show that in the process of carbonization, the phase of magnetite and its magnetic properties are preserved.

According to XRD analysis, the crystal structure of the original $\mathrm{Fe}_{3} \mathrm{O}_{4}$ was characterized by clear reflexes, the most intense of which at

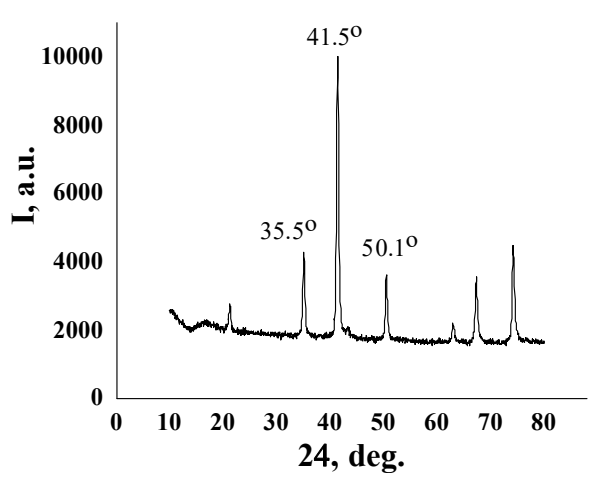

$2 \theta=35.5,41.5,50.1^{\circ}$. The data found (Fig. 1 a) are in good agreement with the crystallographic data of the magnetite phases (JCPDS No. 88315). The results of XRD analysis of samples $\mathrm{Fe}_{3} \mathrm{O}_{4} / \mathrm{Al}_{2} \mathrm{O}_{3}$ and $\mathrm{Fe}_{3} \mathrm{O}_{4} / \mathrm{Al}_{2} \mathrm{O}_{3} / \mathrm{C}$, which were obtained by pyrolysis of NCs $\mathrm{Fe}_{3} \mathrm{O}_{4} / \mathrm{Al}_{2} \mathrm{O}_{3} /$ sucrose at a mass ratio of $\mathrm{Fe}_{3} \mathrm{O}_{4} / \mathrm{Al}_{2} \mathrm{O}_{3} /$ carbohydrate $1.00 / 0.45 \mathrm{~g}$ at $500{ }^{\circ} \mathrm{C}$ in argon for 2 hours, shown in Fig. $1 b$.

Comparison of diffractograms of magnetite, magnetite modified with aluminum isopropylate $\left(\mathrm{Fe}_{3} \mathrm{O}_{4} / \mathrm{Al}_{2} \mathrm{O}_{3}\right)$ and composite $\left(\mathrm{Fe}_{3} \mathrm{O}_{4} / \mathrm{Al}_{2} \mathrm{O}_{3} / \mathrm{C}\right)$, shows their identity, slight decrease in the intensity of reflexes indicates the presence of carbon coating on the surface (Fig. $1 b$ ).

According to the results of mass spectroscopy studies, the use of pyrolysis temperature of $500{ }^{\circ} \mathrm{C}$ in an argon stream for 2 hours allows us to carbonize efficiently the carbohydrate modifier (Fig. 2). In this case, a carbon surface is formed without derivatives and other products characteristic of thermal destruction of carbohydrates, and the main products are $\mathrm{CO}_{2}, \mathrm{CO}$ and $\mathrm{H}_{2} \mathrm{O}$.

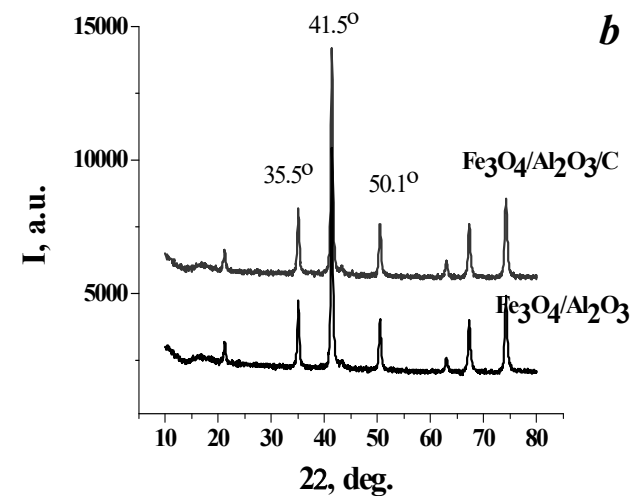

Fig. 1. XRD patterns of NPs of the original $\mathrm{Fe}_{3} \mathrm{O}_{4}(a)$; $\mathrm{NCs} \mathrm{Fe}_{3} \mathrm{O}_{4} / \mathrm{Al}_{2} \mathrm{O}_{3}$ and $\mathrm{Fe}_{3} \mathrm{O}_{4} / \mathrm{Al}_{2} \mathrm{O}_{3} / \mathrm{C}(b)$

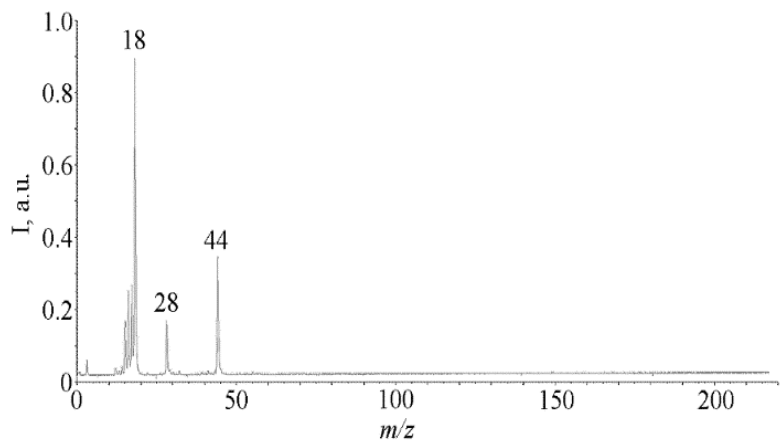

Fig. 2. Mass spectra of $\mathrm{NCs} \mathrm{Fe}_{3} \mathrm{O}_{4} / \mathrm{Al}_{2} \mathrm{O}_{3} / \mathrm{C}$ for temperatures $235{ }^{\circ} \mathrm{C}$ (mass ratio of magnetite/carbohydrate $1.00 / 0.45$, pyrolysis $T=500^{\circ} \mathrm{C}, \tau=2 \mathrm{~h}$, environment is argon) 
Using the superparamagnetic carrier as a probe, the parameters and structure of $\mathrm{NCs}$ $\mathrm{Fe}_{3} \mathrm{O}_{4} / \mathrm{Al}_{2} \mathrm{O}_{3} / \mathrm{C}$ were determined. The hysteresis loops of $\mathrm{Fe}_{3} \mathrm{O}_{4}$ and $\mathrm{NCs} \mathrm{Fe}_{3} \mathrm{O}_{4} / \mathrm{Al}_{2} \mathrm{O}_{3} / \mathrm{C}$ particles are shown in Fig. 3. The calculated value of $\sigma_{\mathrm{s}}=57.9 \mathrm{emu} / \mathrm{g}$ for $\mathrm{Fe}_{3} \mathrm{O}_{4}$ samples is characteristic of nanodispersed magnetite and a decrease in this value for structures $\mathrm{Fe}_{3} \mathrm{O}_{4} / \mathrm{Al}_{2} \mathrm{O}_{3}$ $(51.0 \mathrm{emu} / \mathrm{g})$ and $\mathrm{Fe}_{3} \mathrm{O}_{4} / \mathrm{Al}_{2} \mathrm{O}_{3} / \mathrm{C}(42.4 \mathrm{emu} / \mathrm{g})$ are consistent with the corresponding changes in the mass fraction of $\sigma \mathrm{sNC} / \sigma \mathrm{sFe} \mathrm{O}_{3} \mathrm{O}_{4}$ magnetite in the NCs and indicates the presence of a nonmagnetic shell around the magnetic core.

According to the results of image processing of ensembles of $\mathrm{NPs} \mathrm{Fe}_{3} \mathrm{O}_{4}$ and $\mathrm{Fe}_{3} \mathrm{O}_{4} / \mathrm{Al}_{2} \mathrm{O}_{3} / \mathrm{C}$, obtained by the TEM method, the similarity of shape (Fig. 4) and their average size were found: $\mathrm{Fe}_{3} \mathrm{O}_{4}-10.5 \mathrm{~nm}, \quad \mathrm{Fe}_{3} \mathrm{O}_{4} / \mathrm{Al}_{2} \mathrm{O}_{3} / \mathrm{C}-15.5 \mathrm{~nm}$ (Fig. 5).

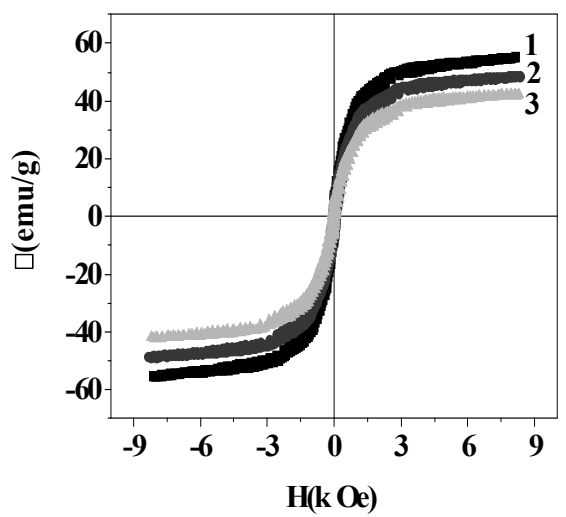

Fig. 3. Magnetic hysteresis loops of the samples: $\mathrm{Fe}_{3} \mathrm{O}_{4}(1)$ and $\mathrm{NCs} \mathrm{Fe}_{3} \mathrm{O}_{4} / \mathrm{Al}_{2} \mathrm{O}_{3}$ (2), $\mathrm{Fe}_{3} \mathrm{O}_{4} / \mathrm{Al}_{2} \mathrm{O}_{3} / \mathrm{C}(3)$
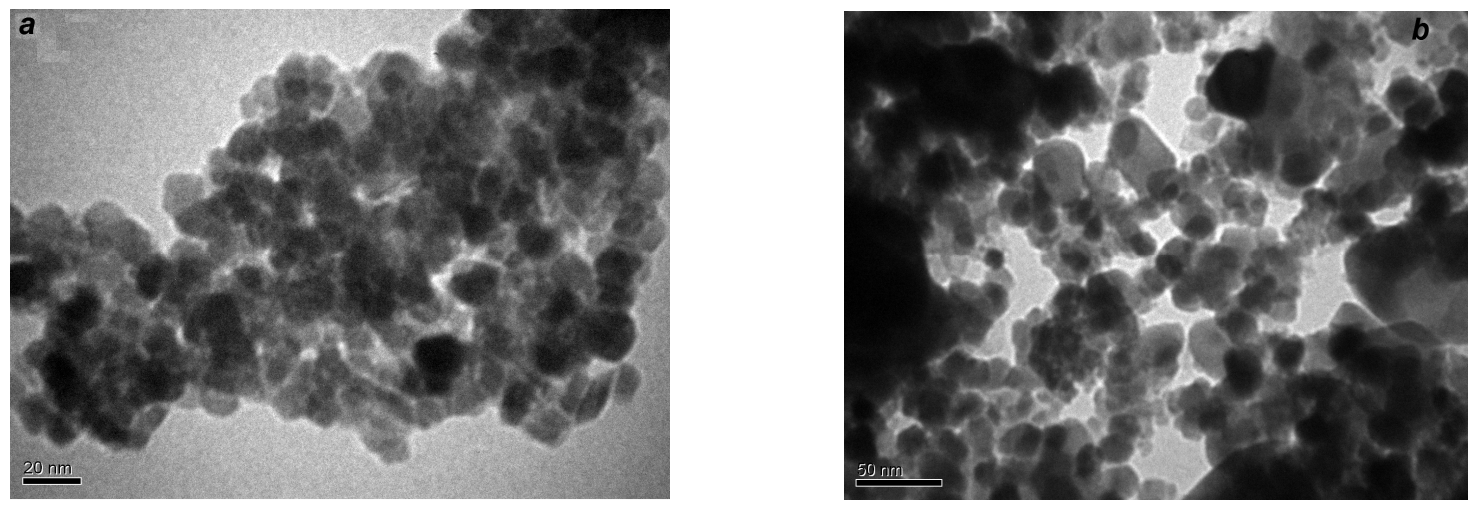

Fig. 4. TEM images of $\mathrm{Fe}_{3} \mathrm{O}_{4} \mathrm{NPs}(a)$ and $\mathrm{NCs} \mathrm{Fe}_{3} \mathrm{O}_{4} / \mathrm{Al}_{2} \mathrm{O}_{3} / \mathrm{C}(b): a$ - scale bar $20 \mathrm{~nm} ; b$ - scale bar $50 \mathrm{~nm}$
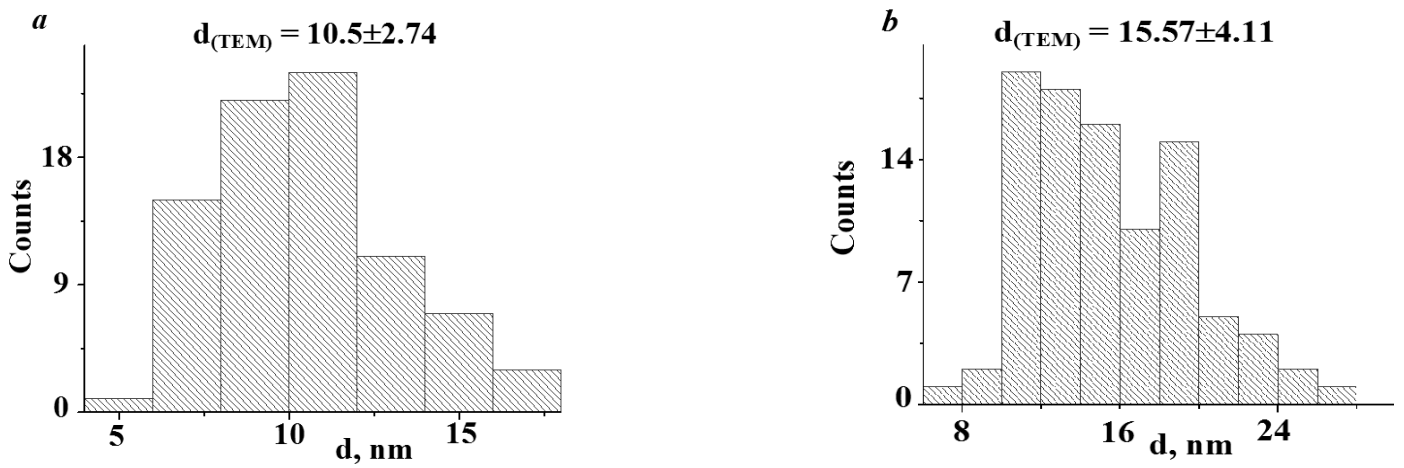

Fig. 5. The corresponding particle size distribution of $\mathrm{Fe}_{3} \mathrm{O}_{4} \mathrm{NPs}(a)$ and $\mathrm{NCs} \mathrm{Fe}_{3} \mathrm{O}_{4} / \mathrm{Al}_{2} \mathrm{O}_{3} / \mathrm{C}(b)$ 
According to the research results of samples, the specific surface area of $\mathrm{NCs} \mathrm{Fe}_{3} \mathrm{O}_{4} / \mathrm{Al}_{2} \mathrm{O}_{3} / \mathrm{C}$ increased to $160 \mathrm{~m}^{2} / \mathrm{g}$, the micropore volume up to $19.27 \mathrm{~mm}^{3} / \mathrm{g}$ and the micropore surface area up to $54.70 \mathrm{~m}^{2} / \mathrm{g}$ (specific surface area of the original magnetite $-110 \mathrm{~m}^{2} / \mathrm{g}$, the volume of micropores $1.16 \mathrm{~mm}^{3} / \mathrm{g}$, surface area of micropores $3.30 \mathrm{~m}^{2} / \mathrm{g}$ ) (Fig. 6, Table 1).

Isotherms according to the IUPAC classification belong to type II and are characterized by the presence of a hysteresis loop, the loop in the high pressure region indicates the presence of slit-like pores. As a result of modification, the parameters of the structure change. The fracture in the middle of the loop of the desorption branch of the isotherm and the presence of a plateau in the low pressure region are associated with the processes of polymolecular nitrogen adsorption and indicate the effect of the developed surface structure obtained as a result of modification (Fig. $6 a$, curve 2). Changes are also recorded in the pore structure: the volume of small diameter pores increases significantly - up to $7.5 \mathrm{~nm}$ (Fig. $6 \mathrm{~b}$, curve 2).
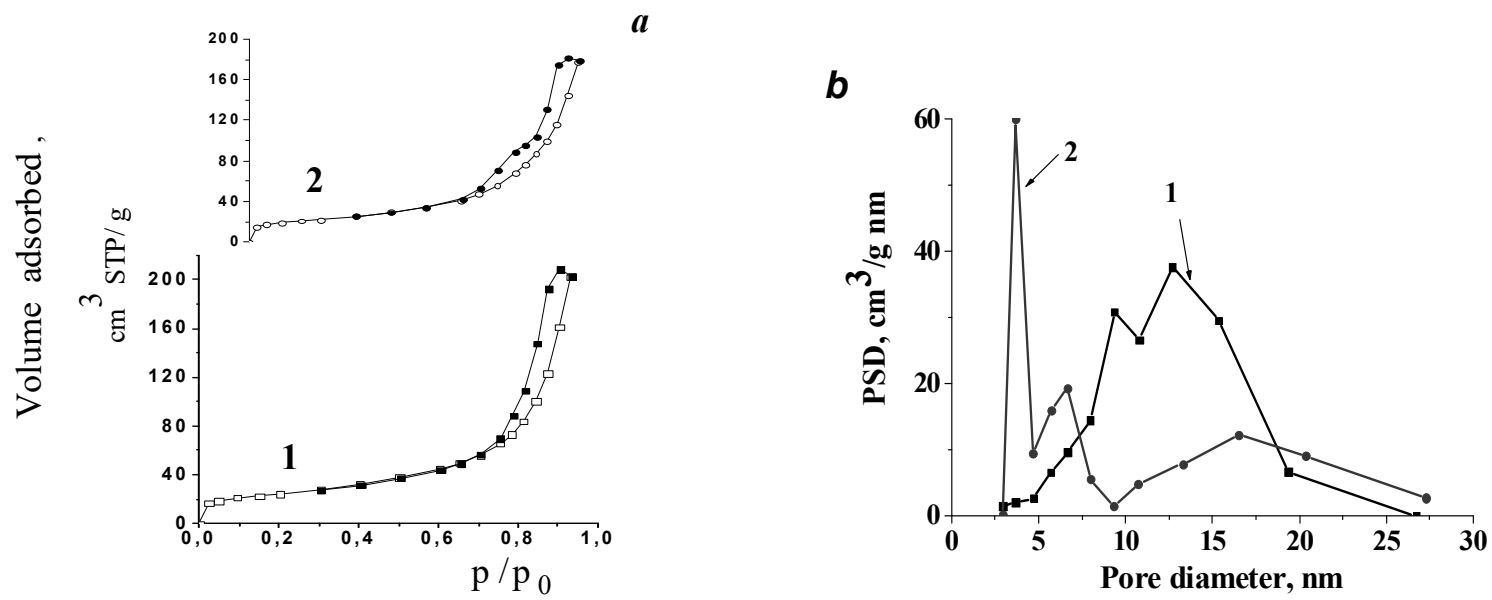

Fig. 6. Adsorption/desorption isotherms (a) and pore distribution (b) of samples: $1-\mathrm{Fe}_{3} \mathrm{O}_{4}, 2-\mathrm{Fe}_{3} \mathrm{O}_{4} / \mathrm{Al}_{2} \mathrm{O}_{3} / \mathrm{C}$

Table 1. The value of the specific surface area and pore size of nanostructures based on magnetite

\begin{tabular}{ccccccc}
\hline Samples & $\begin{array}{c}\text { Langmuir } \\
\text { Surface Area } \\
\mathbf{m}^{2} / \mathbf{g}\end{array}$ & $\begin{array}{c}\text { BET Surface } \\
\text { Area } \mathbf{~ m}^{2} / \mathbf{g}\end{array}$ & $\begin{array}{c}\text { Total pore } \\
\text { volume } \\
\mathbf{c m}^{3} / \mathbf{g}\end{array}$ & $\begin{array}{c}\text { Micropore } \\
\text { volume } \\
\mathbf{m m}^{3} / \mathbf{g}\end{array}$ & $\begin{array}{c}\text { Micropore } \\
\text { area } \\
\mathbf{m}^{2} / \mathbf{g}\end{array}$ & $\begin{array}{c}\text { Non- } \\
\text { microporous } \\
\text { Surface Area } \\
\mathbf{m}^{2} / \mathbf{g}\end{array}$ \\
\hline $\mathrm{Fe}_{3} \mathrm{O}_{4}$ & 110.2 & 86.2 & 0.31 & 1.16 & 3.3 & 82.9 \\
$\mathrm{Fe}_{3} \mathrm{O}_{4} / \mathrm{Al}_{2} \mathrm{O}_{3} / \mathrm{C}$ & 160.4 & 114.8 & 0.25 & 19.27 & 54.7 & 60.1 \\
\hline
\end{tabular}

The adsorption characteristics of a chemotherapeutic drug Cisplatin on the surface of $\mathrm{Fe}_{3} \mathrm{O}_{4} / \mathrm{Al}_{2} \mathrm{O}_{3} / \mathrm{C}$ were studied. Adsorption of drugs can be one of the effective ways to create drugs of prolonged action and adsorption materials.

Cisplatin is an antitumor drug that is massproduced by the industry in the form of a solution. The active substance is a complex of cis-diaminodichloroplatinum (cis-[Pt $\left.\left(\mathrm{NH}_{3}\right)_{2} \mathrm{Cl}_{2}\right]$ ). The mechanism of antitumor action of cisplatin is associated with the capability to alkylate DNA bifunctionally, resulting in disruption of replication and transcription and leads to delayed cell cycle and apoptosis [21, 22].

Effect of initial pH on the Cisplatin adsorption. The dependence of $\mathrm{CP}$ adsorption on the surface of the nanocomposite on $\mathrm{pH}$ is investigated (Fig. 7). The absence of changes in the spectral characteristics under experimental conditions ( $\mathrm{pH}$ range $3-9.6$, medium $0.9 \% \mathrm{NaCl}$ solution) indicates the stability of the complex $\left[\mathrm{Pt}\left(\mathrm{NH}_{3}\right)_{2} \mathrm{Cl}_{2}\right]$, which matches the data [23] (Fig. 8). The maximum degree of extraction is fixed in a weakly acidic environment ( $\mathrm{pH}$ 5.5-6.5). 


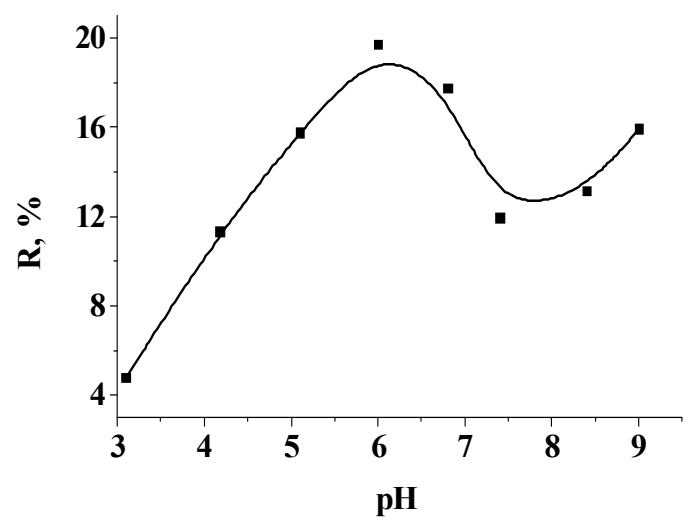

Fig. 7. Dependence of the degree of extraction on $\mathrm{pH}$



Fig. 8. UVspectra of cisplatinin $0.9 \% \mathrm{NaCl}$ solution atdifferent $\mathrm{pH}: 1-3.6 ; 2-4.6 ; 3-5.6$; $4-6.6 ; 5-7.6 ; 6-8.6 ; 7-9.6$

Study and model ling kinetics of adsorption.

One of the conditions for the use of

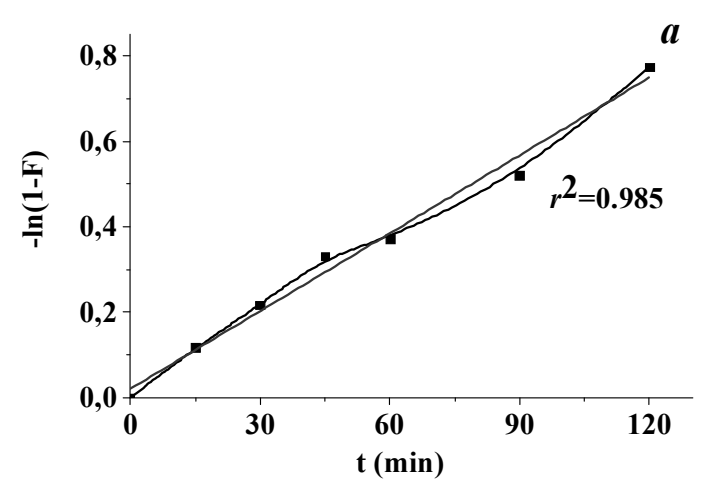

nanocomposites for targeted delivery and as adsorption materials is the rapid interaction of the substances with the surface of NPs. Therefore, the subject of the study was the mechanism of shortterm (up to $180 \mathrm{~min}$ ) contact of the drug solution with the surface of NCs. The experimental dependence of the value of Cisplatin adsorption $(A \mathrm{mg} / \mathrm{g})$ on the contact time $(t \mathrm{~min})$ for the nanocomposite $\mathrm{Fe}_{3} \mathrm{O}_{4} / \mathrm{Al}_{2} \mathrm{O}_{3} / \mathrm{C}$ at values of $C_{0}=0.0326 \mathrm{mg} / \mathrm{ml}$ is shown in Fig. 9 .

The results of kinetic studies in the coordinates $-\ln (1-F)-t$ (Boyd diffusion model [24], (Fig. 10a)) and $F-t^{0.5}$ (Morris-Weber model (Fig. $10 \mathrm{~b}$ )), respectively) were analyzed, which are used to determine the external or intradiffusion limitation of adsorption [25].

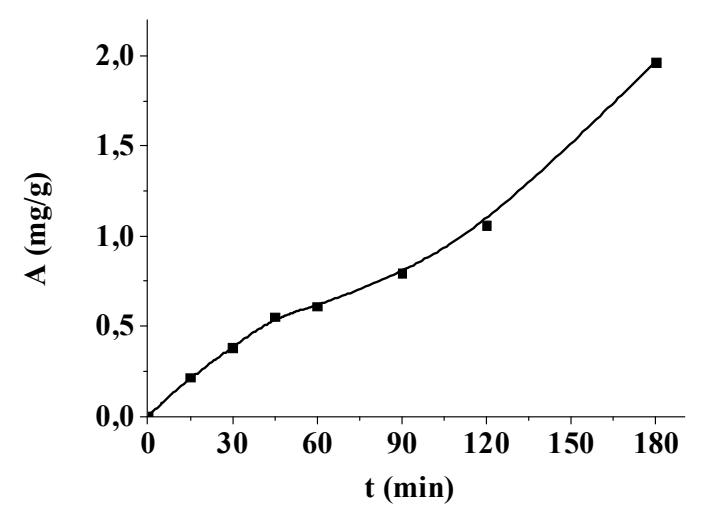

Fig. 9. Experimental dependence of the value of Cisplatin adsorption on the contact time on samples of $\mathrm{Fe}_{3} \mathrm{O}_{4} / \mathrm{Al}_{2} \mathrm{O}_{3} / \mathrm{C}$ nanocomposite



Fig. 10. Experimental kinetic dependences of Cisplatin adsorption in the coordinates $--\ln (1-F)-t(a)$ and $F-t^{0.5}(b)$

The linear dependence, with a high correlation coefficient, for the Boyd diffusion model (Fig. $10 a$ ) indicates a significant influence of the external diffusion sorption process and a small influence of film diffusion on the sorption process.
The linearity of the initial section of the dependence $F-t^{0.5}$ (Fig. $10 \mathrm{~b}$ ) indicates the predominance of surface processes and indicates the effect of the boundary layer, at the same time there is no contribution of intradiffusion 
processes (diffusion within particles or pores) in the overall process speed.

To determine the limiting kinetic process external or intraparticle diffusion, the data were analyzed using the Boyd kinetic equation:

$$
F=1-\frac{6}{\pi^{2}} \sum_{n=1}^{n=\infty} \frac{1}{n^{2}} \exp \left(-B n^{2}\right)
$$

Converting the resulting equation

$$
B_{t}=-0.4977-\ln (1-F)
$$

which is used to calculate the value of $B_{\mathrm{t}}$ for different values of $t$.
The $B_{t}-t$ dependence was used to distinguish the limiting influence of external and intraparticle diffusion (Fig. 11).

Linearity in the coordinates $B_{t}-t$ (Fig. 11) indicates a limitation of the sorption rate by external diffusion. The calculated values of $B_{\mathrm{t}}$ were used to calculate the effective diffusion coefficient: $D_{\text {avg }} \cdot 10^{-13}=0.065\left(\mathrm{~cm}^{2} / \mathrm{s}\right)$.

Experimental results were checked for compliance with the kinetic models of the pseudo-first and pseudo-second order (Fig. $12 a, b)[26,27]$.

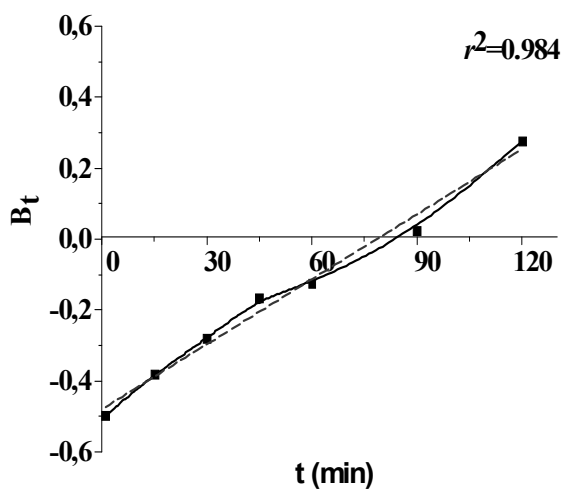

Fig. 11. $\quad B_{t}-t$ dependence for Cisplatin adsorption
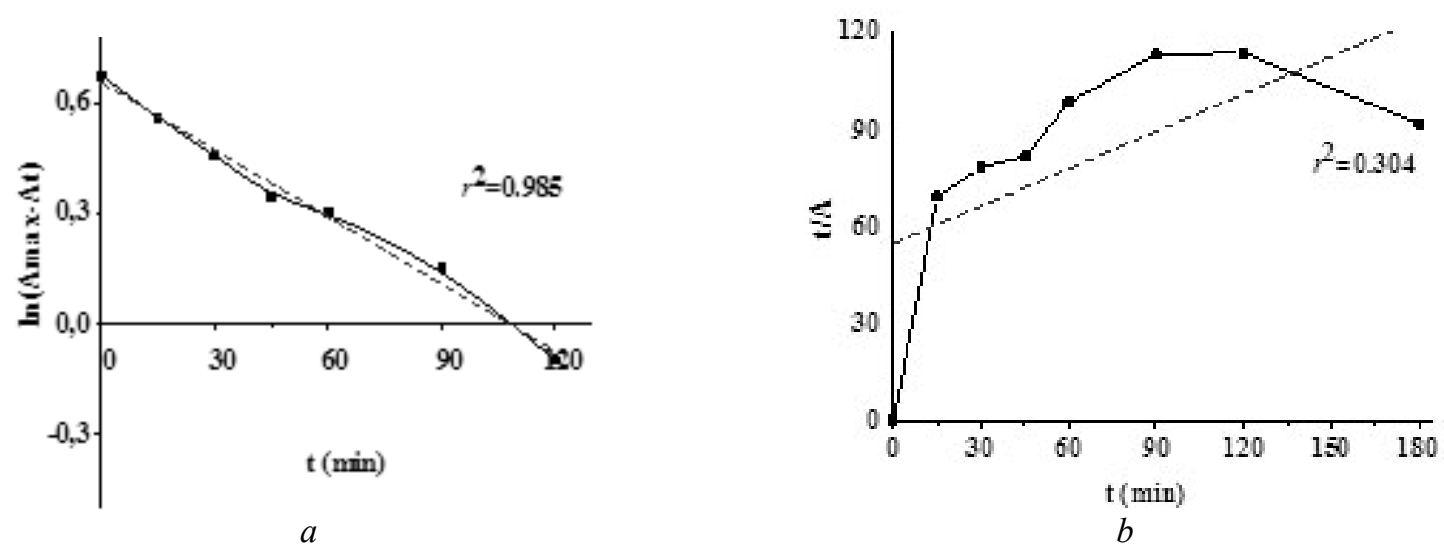

Fig. 12. Kinetic dependences of Cisplatin adsorption in the coordinates of the pseudo-first order model $(a)$ and the pseudo-second order model $(b)$

It is found (Fig. $12 a$ ) that the experimental curve in the coordinates of the pseudo-firstorder equation are described with a high value of the correlation coefficient $\left(r^{2}=0.985\right)$ (Table 2). For a pseudo-second-order model that takes into account the sorbent-sorbate chemical interaction and the intermolecular interactions of the sorbed substances, a nonlinear dependence is recorded
(Fig. $12 b$ ). The obtained results correlate with the results of processing of kinetic curves using the model of external diffusion limitation of the adsorption process and the existence of nonhydrolyzed ionic forms of Cisplatin in solution.

Study and modelling adsorption equilibrium. Langmuir and Freundlich models were used to quantitatively describe the 
equilibrium adsorption processes. Linearized equations of these models are used to determine the values of the constants included in the isotherm equation. The results of mathematical processing of experimental results are shown in Fig. 13 and in the Table 3.
The highest correlation coefficient $r^{2}=0.977$, the correlation of theoretical and practically obtained values of adsorption capacity indicates the possibility of using the Freindlich model to describe the adsorption of Cisplatin on the surface of $\mathrm{Fe}_{3} \mathrm{O}_{4} / \mathrm{Al}_{2} \mathrm{O}_{3} / \mathrm{C}$.

Table 2. Kinetic characteristics of Cisplatin adsorption

\begin{tabular}{ll}
\hline Pseudo-first order model & \\
\hline & $C_{0}=0.0326 \mathrm{mg} / \mathrm{ml}$ \\
\hline$A_{\text {exp }}(\mathrm{mg} / \mathrm{g})$ & 1.965 \\
$A_{\text {calc }}(\mathrm{mg} / \mathrm{g})$ & 1.921 \\
$k, \mathrm{~min}^{-1}$ & 0.0061 \\
$r^{2}$ & 0.985 \\
\hline
\end{tabular}

Note: $k$ is the sorption rate constant of the pseudo-first order $\left(\mathrm{min}^{-1}\right)$

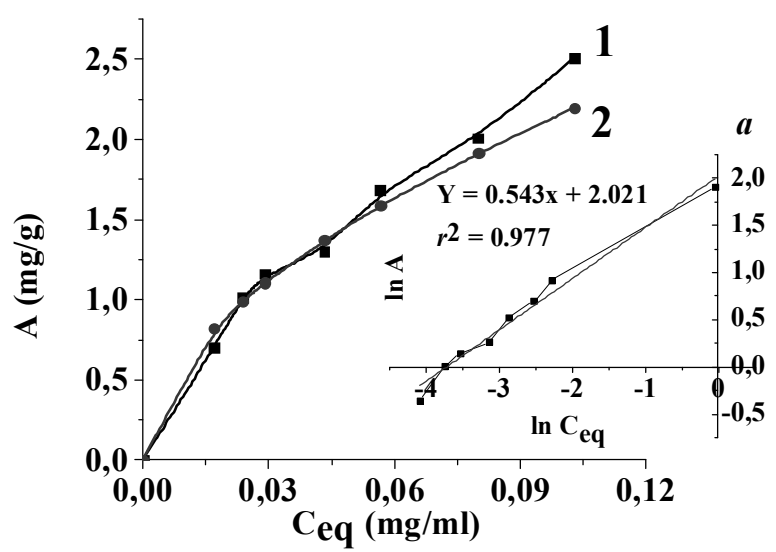

Fig. 13. Isotherms of Cisplatin adsorption on $\mathrm{NCs} \mathrm{Fe}_{3} \mathrm{O}_{4} / \mathrm{Al}_{2} \mathrm{O}_{3} / \mathrm{C}$ obtained from adsorption experiment (1); calculated from the parameters of the Freundlich equation (2); linearized form of Freundlich isotherm $(a)$

Table 3. Parameters of Cisplatin adsorption on $\mathrm{NCs} \mathrm{Fe}_{3} \mathrm{O}_{4} / \mathrm{Al}_{2} \mathrm{O}_{3} / \mathrm{C}$ calculated using Freundlich models

\begin{tabular}{lccccc}
\hline Equation & \multicolumn{5}{c}{$A_{p}=K_{F} C_{p}{ }^{1 / n}$} \\
\hline Linearized form & \multicolumn{5}{c}{$\ln A_{p}=\ln K_{F}+(1 / n) \ln C_{p}$} \\
\hline Calculated parameters & $A_{\text {exp }}, \mathrm{mg} / \mathrm{g}$ & $A_{\text {cal }}, \mathrm{mg} / \mathrm{g}$ & $K_{F}$ & $1 / n$ & $r^{2}$ \\
\hline$C_{0}=0.0211-0.118 \mathrm{mg} / \mathrm{ml}$ & 2.196 & 2.196 & 7.54 & 0.54 & 0.977 \\
\hline
\end{tabular}

\section{CONCLUSIONS}

The processes of pyrolytic carbonization of sucrose-containing coatings on the surface of single-domain magnetite have been studied. It is shown that in the mass spectra of $\mathrm{Fe}_{3} \mathrm{O}_{4} / \mathrm{Al}_{2} \mathrm{O}_{3} / \mathrm{C}$ nanocomposites, the main pyrolysis products are $\mathrm{CO}_{2}, \mathrm{CO}$ and water, which indicates the efficiency of the carbonization process of the carbohydrate coating. It is found that the used heat treatment mode $\left(500{ }^{\circ} \mathrm{C}\right.$ for $2 \mathrm{~h}$ in an argon stream) does not lead to deterioration of the magnetic characteristics of magnetite under the condition of preliminary creation of a protective layer of alumina on its surface. The TEM method proved that in all studied samples of $\mathrm{Fe}_{3} \mathrm{O}_{4}, \mathrm{Fe}_{3} \mathrm{O}_{4} / \mathrm{Al}_{2} \mathrm{O}_{3} / \mathrm{C}$ the shape of the NPs is similar, their average size is $\mathrm{Fe}_{3} \mathrm{O}_{4}-10.5 \mathrm{~nm}$, $\mathrm{Fe}_{3} \mathrm{O}_{4} / \mathrm{Al}_{2} \mathrm{O}_{3} / \mathrm{C}-15.5 \mathrm{~nm}$.

The adsorption of the antitumor drug cisplatin on the surface of $\mathrm{NCsFe}_{3} \mathrm{O}_{4} / \mathrm{Al}_{2} \mathrm{O}_{3} / \mathrm{C}$ were studied. Adsorption processes depending on contact time, solution $\mathrm{pH}$ and cisplatin 
concentration were studied. The kinetics of cisplatin adsorption corresponds to the pseudofirstorder model $\left(r^{2}=0.985\right)$, the limiting factor of adsorption is the process of external diffusion. Equilibrium adsorption of Cisplatin corresponds to the Freundlich model $\left(r^{2}=0.977\right)$.
The results of the work can be used in the development of new magnetically controlled adsorption materials for ecological and medicalbiological purposes, teranostic means of targeted delivery, etc.

\title{
Адсорбція цисплатину на поверхні магніточутливого нанокомпозиту $\mathrm{Fe}_{3} \mathrm{O}_{4} / \mathrm{Al}_{2} \mathrm{O}_{3} / \mathrm{C}$
}

\author{
П.П. Горбик, А.Л. Петрановська, Н.В. Кусяк, Н.М. Корнійчук, А.П. Кусяк, \\ О.І. Оранська, Т.В. Кулик, Б.Б. Паляниця, О.А. Дударко \\ Інститут хімії поверхні ім. О.О. Чуйка Національної академії наук Украӥни \\ вул. Генерала Наумова, 17, Киї, 03164, Україна, petranovska@ukr.net \\ Житомирський державний університет імені Івана Франка \\ вул. В.Бердичівська 40, Житомир, 10008, Україна
}

Одним з найбільш широко використовуваних протипухлинних хіміотерапевтичних препаратів $\epsilon$ «Цисплатин» (діюча речовина - цис-діамінодихлороплатина), побічними ефектами використання якого $\epsilon$ кумулятивна ототоксична, нефротоксична та нейротоксична дія. Мінімізація небажаних ефектів без зниження терапевтичної дї цисплатину може бути досягнута з використанням носіїв ліків, зокрема магнетит-вуглецевих нанокомпозитів.

3 иією метою синтезовано нанокомпозит $\mathrm{Fe}_{3} \mathrm{O}_{4} / \mathrm{Al}_{2} \mathrm{O}_{3} / \mathrm{C}$ з вуглецевою поверхнею, де прошарок оксиду алюмінію захищає магнетит при піролізі вуглеводнів. Синтезовані зразки охарактеризовані методами ТЕМ, $X R D$, мас-спектрометрії, досліджено магнітні властивості та величину питомої поверхні. Встановлено, щзо використаний режим термообробки $\left(T=500{ }^{\circ} \mathrm{C}\right.$, середовище аргону) достатній для повної карбонізації сахарози та зберігає фазу магнетиту, щзо не призводить до погіршення магнітних характеристик. Результати ТЕМ-досліджень $i$ магнітних вимірювань свідчать про формування нанокомпозиту $\mathrm{Fe}_{3} \mathrm{O}_{4} / \mathrm{Al}_{2} \mathrm{O}_{3} / \mathrm{C}$ типу ядро-оболонка.

Проведено адсорбцію ичисплатину на поверхні $\mathrm{HK} \mathrm{Fe}_{3} \mathrm{O}_{4} / \mathrm{Al}_{2} \mathrm{O}_{3} / \mathrm{C}$; процес адсорбиії вивчено в залежності від часу контакту, рН розчину $і$ концентрації цисплатину. Експериментальні результати кінетичних досліджень проаналізовано на відповідність теоретичним моделям Бойда та Морриса-Вебера, моделям псевдоперщзго і псевдодругого порядків. Моделі ізотерм Ленгмюра та Фрейндліха використано для аналізу проиесів адсорбиії. Лімітуючим фактором адсорбиії $\epsilon$ зовнішньодифузійні проиеси масопереносу, щзо корелює з розрахованими параметрами моделі псевдопершого порядку $\left(r^{2}=0.985\right)$. Кореляція теоретичних та практично отриманих величин адсорбиійної ємності вказує на можслвість застосування моделі Фрейндліха для опису адсорбиії ичисплатину на поверхні $\mathrm{Fe}_{3} \mathrm{O}_{4} / \mathrm{Al}_{2} \mathrm{O}_{3} / \mathrm{C}$.

Ключові слова: магніточутливі нанокомпозити, вуглецева поверхня, карбонізація, Цисплатин, адсорбція

\section{REFERENCES}

1. Kim E., Lee K., Huh Y.-M., Haam S. Magnetic nanocomplexes and the physiological challenges associated with their use for cancer imaging and therapy. J. Mater. Chem. B. 2013. 1: 729.

2. Gorbyk P.P., Kusyak N.V., Petranovskaya A.L., Oranskaya E.I., Abramov N.V., Opanashchuk N.M. Synthesis and properties of magnetic nanostructures with carbonized surface. Him. Fiz. Tehnol. Poverhni. 2018. 9(2): 176. [in Ukrainian].

3. Xu Y., Heberlein W.E., Mahmood M., Orza A.I., Karmakar A., Mustafa T., Biris A.R., Casciano D., Biris A.S. Progress in materials for thermal ablation of cancer cells. J. Mater. Chem. 2012. 22(38): 20128.

4. Zhu M., Wang C., Menga D., Diao G. In situ synthesis of silver nanostructures on magnetic $\mathrm{Fe}_{3} \mathrm{O}_{4} @ \mathrm{C}$ coreshell nanocomposites and their application in catalytic reduction reactions. J. Mater. Chem. A. 2013. 1(6): 2118. 
5. Wan L., Yan D., Xu X., Li J., Lu T., Gao Y., Yao Y., Pan L. Self-assembled 3D flower-like $\mathrm{Fe}_{3} \mathrm{O}_{4} / \mathrm{C}$ architecture with superior lithium ion storage performance. J. Mater. Chem. A. 2018. 6(48): 24940.

6. Gorbyk P.P. Nanocomposites with functions of medico-biological nanorobots: synthesis, properties, application. Nanosystems, Nanomaterials, Nanotechnologies. 2013. 11(2): 323. [in Ukrainian].

7. Shpak A.P., Gorbyk P.P. Nanomaterials and Supramolecular Structures. (Springer, Dordrecht, 2010).

8. Patent UA 99211. Gorbyk P.P., Petranovska A.L., Turelyk M.P., Turanska S.P., Vasylieva O.A., Chekhun V.F., Luk'yanova N.Yu., Shpak A.P., Korduban O.M. Nanocapsule with nanorobot functions. 2012.

9. Gorbyk P.P., Lerman L.B., Petranovska A.L., Turanska S.P. Magnetosensitive Nanocomposites with Functions of Medico-Biological Nanorobots: Synthesis and Properties. In: Advances in Semiconductor Research: Physics of Nanosystems, Spintronics and Technological Applications. (New York: Nova Science Publishers, 2014).

10. Gorbyk P.P., Lerman L.B., Petranovska A.L., Turanska S.P., Pylypchuk I.V. Magnetosensitive Nanocomposites with Hierarchical Nanoarchitecture as Biomedical Nanorobots: Synthesis, Properties, and Application. In: Fabrication and Self-Assembly of Nanobiomaterials, Applications of Nanobiomaterials. (Elsevier, 2016).

11. Abramov M.V., Kusyak A.P., Kaminskiy O.M., Turanska S.P., Petranovska A.L., Kusyak N.V., Gorbyk P.P. Magnetosensitive Nanocomposites Based on Cisplatin and Doxorubicin for Application in Oncology. In: Horizons in World Physics. V. 293. (New York, Nova Science Publisher, 2017). P. 1-56.

12. Petranovska A.L., Abramov N.V., Turanska S.P., Gorbyk P.P., Kaminskiy A.N., Kusyak N.V. Adsorption of cis-dichlorodiammineplatinum by nanostructures based on single-domain magnetite. J. Nanostruct. Chem. 2015. 5: 275.

13. Abramov M.V., Petranovska A.L., Kusyak N.V., Kusyak A.P., Opanashchuk N.M., Turanska S.P., Gorbyk P.P., Luk'yanova N.Yu., Chekhun V.F. Synthesis and properties of magnetosensitive nanocomposites and ferrofluids based on magnetite, gemcitabine and HER2 antibody. Funct. Mater. 2020. 27(2): 283.

14. Abramov N.V., Turanska S.P., Kusyak A.P., Petranovska A.L., Gorbyk P.P. Synthesis and properties of magnetite/hydroxyapatite/doxorubicin nanocomposites and magnetic fluids based on them. J. Nanostruct. Chem. 2016. 6: 223.

15. Gorbyk P.P. Biomedical nanocomposites with nanorobot functions: state of research, development, and prospects of practical introduction. Him. Fiz. Tehnol. Poverhni. 2020. 11(1): 128. [in Ukrainian].

16. Zhang R., Olin H. Carbon nanomaterials as drug carriers: Real time drug release investigation. Mater. Sci. Eng. C. 2012. 32(5): 1247.

17. Selwood P. Magnetochemistry. (Moscow: Publishing house of foreign. Lit., 1958).

18. Petranovskaya A.L., Usov D.G., Abramov M.V, Demchenko Yu.O., Corduban O.M. Modification of the surface of nanocrystalline magnetite with aluminum isopropoxide. Chemistry, Physics and Surface Technology. 2007. 13: 310.

19. Kulik T., Palianytsia B., Larsson M. Catalytic Pyrolysis of Aliphatic Carboxylic Acids into Symmetric Ketones over Ceria-Based Catalysts: Kinetics, Isotope Effect and Mechanism. Catalysts. 2020. 10(179): 1.

20. Kulyk K., Zettergren H., Gatchell M., Alexander J.D., Larsson M., Borysenko M., Palianytsia B., Kulik T. Dimethylsilanone Generation from Pyrolysis of Polysiloxanes Filled with Nanosized Silica and Ceria/Silica. ChemPlusChem. 2016. 81(9): 1003.

21. Dasari S., Tchounwou B.P. Cisplatin in cancer therapy: Molecular mechanisms of action. Eur. J. Pharmacol. 2014. 740: 364 .

22. De Biasi A.R., Villena-Vargas J., Adusumilli P.S. Cisplatin-Induced Antitumor Immunomodulation: A Review of Preclinical and Clinical Evidence. Clin. Cancer Res. 2014. 20(21): 5384.

23. Skvortsov A.N. Efficient method of analysis of optical spectra from kinetic studies. Cytology. 2009. 51(3): 229. [in Russian].

24. Boyd G.E., Adamson A.W., Myers L.S. The exchange adsorption of ions from aqueous solution by organic zeolites. II. Kinetics. J. Am. Chem. Soc. 1947. 69(11): 2836.

25. Gupta V.K., Ali I. Removal of DDD and DDE from wastewater using bagasse fly ash, a sugar industry waste. Water Res. 2001. 35(1): 33.

26. Ho Y.S., Ng J.C.Y., McKay G. Kinetics of pollutant sorption by biosorbents: review. Sep. Purif. Methods. 2000. 29(2): 189.

27. Douven S., Paez C.A., Gommes C.J. The range of validity of sorption kinetic models. J. Colloid Interface Sci. 2015. 448: 437 . 